\title{
The new public corruption: Old questions for new challenges
}

\author{
Giuseppe Grossi ${ }^{\mathrm{a}, *}$, Daniela Pianezzi ${ }^{\mathrm{b}, 1}$ \\ a Section of Health and Society, Kristianstad University, 29188 Kristianstad, Sweden \\ b Institute of Management, Scuola Superiore Sant'Anna, 56127 Pisa, Italy
}

\section{A R T I C L E I N F O}

\section{Article history:}

Received 30 March 2015

Received in revised form 1 March 2016

Accepted 1 May 2016

Available online xxx

\section{Keywords:}

Corruption

Public procurement

Accountability

New public governance

New public management

Social contract

\begin{abstract}
A B S T R A C T
This paper focuses on corruption in public procurement. It describes the contemporary face of corruption by investigating the role of public accountability in the fight against corruption. The paper describes a specific episode of corruption relative to the awarding of government contracts for big events, such as the celebration of the 150th anniversary of Italian unification. Relying on the philosophical insights of Rousseau, Popper, Kant and others, the study suggests the need for enabling a democratic control and constructing a public ethics for the common good.
\end{abstract}

(c) 2016 Elsevier Ltd. All rights reserved.

\section{Introduction}

Corruption is a pervasive worldwide phenomenon. More than one in four people around the world report having paid a bribe (Transparency International, 2013) and the losses caused by the spread of corruption amount to more than $5 \%$ of the world's GDP (OECD, 2013b). Both developed and democratic as well as developing countries are not free from corruption (Bayley, 1966; Neu, Everett, Rahaman, \& Martinez, 2013). However, in advanced countries, corruption emerges with more significant economic and social costs (EU Anti-Corruption Report, 2014; Kenny \& Musatova, 2010; Rose-Ackerman \& Stone, 1996). Therefore, an extensive amount of interdisciplinary literature has explored the negative effects of corruption (e.g., loss of governance capacity, decrease of economy growth, income inequality or erosion of competitiveness) and the conditions under which corruption is likely to take place (e.g., inefficient management, a weak normative environment, lack of transparency and controls or an ineffective penalty system) (Everett, Neu, \& Rahaman, 2006; Fjeldstad \& Tungodden, 2003; Graycar \& Villa, 2011; Sikka \& Lehman, 2015).

The term corruption comes from the Latin 'corrumpere', meaning to destroy or adulterate, and it is somewhat of a vague concept, as it could refer to a broad range of behaviours (e.g., nepotism, bribery, embezzlement, favouritism or conflict of interest) (Everett et al., 2006; Klitgaard, 2014). Here, we use the word corruption in reference to 'the illegitimate use of public or communal resources for private gain' (Neu, Everett, \& Rahaman, 2015, p. 2; see also World Bank, 1997; International Monetary Fund, 2005). In spite of the ambiguity of the term, there seems to be general agreement in the literature that the state has a pivotal role in fighting corruption, while there are conflicting perspectives on the specific tasks that it should

\footnotetext{
* Corresponding author. Tel.: +46 044203125.

E-mail addresses: giuseppe.grossi@hkr.se (G. Grossi), daniela.pianezzi@sssup.it (D. Pianezzi).

1 Postal address: Via Cavour, 89, 21047 Saronno, Italy.
} 
undertake and perform to carry out this objective (Hopkin \& Rodríguez-Pose, 2007). Therefore, different solutions have been proposed to prevent and combat this phenomenon.

Some authors suggest that internal controls and surveillance systems could be the most powerful ways to prevent corruption (Neu et al., 2015). Hopkin and Rodríguez-Pose (2007) identify government regulation as the point at which corruption can first arise. This "control solution" (Everett et al., 2006, p. 6) points to the need of effective legal and institutional systems of anti-corruption that are capable of detecting and preventing corrupt practices when they first begin to emerge. However, there are countries in which the existence of anti-corruption laws is of a merely symbolic nature, and 'anti-corruption assemblages can be eternally optimistic yet perpetually failing' (Sargiacomo, Ianni, D’Andreamatteo, \& Servalli, 2015, p. 96). This is the case of countries like Greece, Italy and Brazil, where an institutional and legal anti-corruption framework is in place, yet enforcement is only sporadic (Transparency International, 2014) due to (among other factors) the excessive complexity of the rules, the overlapping of competences and the length of judicial proceedings (European Commission, 2014a, 2014b; Transparency International, 2014). In these settings, auditing and inscription processes may be inadequate to face or prevent corruption (Roberts, 2015; Sargiacomo et al., 2015; Sikka \& Lehman, 2015).

On the other hand, other scholars (including Khanal, 2000; Rose-Ackerman, 2000; Shleifer \& Vishny, 2002) and international organizations such as the World Bank and the International Monetary Fund (Everett et al., 2006) suggest that a 'minimal state' can be a remedy for corruption. The neoliberal belief in the superiority of the market economy that underlies this reasoning leads to the conclusion that one of the most effective ways to reduce corruption is to limit state intervention through decentralization, privatization, outsourcing, deregulation and downsizing. The neoliberal approach to corruption especially encourages the practice of outsourcing, and therefore in the last few decades, the interaction between the government and the market in public procurement (Berrios, 2006; Lessig, 2011) has reached an unprecedented scale (Argyriades, 2010). According to the United Nations Office of Drugs and Crime (2013), procurement is estimated to account for 15-30\% of the GDP of many countries.

In line with these 'exit strategies' (Everett et al., 2006, p. 5), two public administration paradigms are dominant today: the new public management and the new public governance. New public management symbolizes the second major wave of neoliberalism (Morales, Gendron, \& Guénin-Paracini, 2014) and assumes the public goodness of the management of private corporations (Stiglitz, 1989) to improve the efficiency and effectiveness of the public sector. New public governance's paradigm endorses a hollow state (Foster \& Plowden, 1996) that downsizes public sectors by transferring government functions to third-party contractors (Agranoff, 2008; Valkama, Bailey, \& Anttiroiko, 2013). This system implies horizontal relationships between governments and other organizations (Almquist, Grossi, van Helden, \& Reichard, 2013; Bevir, 2006) and is structured around the empirical phenomenon of policy issues or public services that are solved within networks of actors' (Klijn, 2012, p. 206; Kooiman, 2003).

However, the modern age dominated by these paradigms still offer fertile ground for corrupt practices (Hansson \& Holmgren, 2011; Kelleher \& Yackee, 2009; Roberts, 2015; Sikka \& Lehman, 2015). Some authors suggest that when economic entities provide public services, then there is often an 'increased decentralization of responsibilities' (Grossi \& Reichard, 2008, p. 611) and a lack of accountability (Haque, 2001). New public governance transforms the relationship between the citizens and the state into a 'marketized triangular public-service structure' (Crouch, Eder, \& Tambini, 2000, p. 91), in which the intermediate providers that serve the citizen-customer on behalf of the elected representatives are not forced to be accountable to the citizens.

Furthermore, the relegation of public functions to non-governmental actors, the adoption of business-like practices in the public sector and the consequent change from government to governance (OECD, 2001) may raise certain ethical issues (Argyriades, 2010; Frederickson, 1996, 1999; Gilmour \& Jensen, 1998; Kolthoff, Huberts, \& Van den Heuvel, 2006; Lane, 1994). According to Argyriades (2010), this paradigmatic shift (Osborne \& Gaebler, 1993) has changed the role and the image of the public servant, leading to a loss of professional autonomy. Frederickson (1999) argues that the new public management project multiplies the opportunities for corruption since it encourages public officials' selfish behaviours. Accordingly, Morales et al. (2014) conclude that 'private sector mentalities and practices increasingly influence how the state is conceived of and managed to the point that members of central governments and public servants come to think and behave increasingly like business entrepreneurs' (p. 424). In addition, given that 'corruption is often private-to-private' (Everett et al., 2006, p. 9), a drastic curtailing of the role of the state in the economy does not necessarily entail a reduction of corruption. On this issue, Hopkin and Rodríguez-Pose (2007) claim that 'corruption can be defeated without abandoning the state's role in protecting society from the rough edges of the market economy' (p. 202).

Indeed, despite the case of the United States, which ranks 16th in the Corruption Perception Index (CPI), (Transparency International, 2015), seems to suggest a positive correlation between neoliberalism and a low level of corruption (see Johnston, 2015, for an extensive analysis of the peculiarity of the United States' case), the position at the top of the CPI (Transparency International, 2015) of countries such as Sweden and Denmark, where the role of the state is traditionally very strong, confirm that neoliberalism is not a 'best fit for all' solution. To the contrary, in these Northern countries, the introduction of neoliberal mechanisms seems to raise many concerns in terms of controlling corruption because 'resources that previously were administered and controlled by public law now fall under civil law' (European Commission, 2014d, p. 6) and mechanisms of transparency and public control appear to be relatively weak in the private sphere.

This paper contributes to this growing debate about the development of effective anti-corruption strategies by focusing on the role that accountability can play in fighting corruption. Accountability is here defined as both a mechanism and 
a virtue. Accordingly, the research investigates the reciprocal implication of accountability and legitimacy of power, and the mechanisms leading to the misuse of the public interest. It then leads to a deeper examination into the overlooked relationship between public procurement and democratic accountability (Murray, 2009), thus revealing the limitations of the neoliberal approach to corruption.

In particular, this paper enriches the existing critical accounting literature on corruption that has previously investigated the mechanisms that construct the public official as an ethical subject while also examining the role of ethics in fighting corruption (Everett et al., 2006; Hoskin, 2015; Johnston, 2015; Neu et al., 2013; Neu et al., 2015; Roberts, 2015; Sargiacomo et al., 2015; Sikka \& Lehman, 2015). Indeed, the literature sheds little light on the ethical implications raised by the growing role of external providers (i.e., private and non-profit enterprises) in public procurement (Hawkins, Gravier, \& Powley, 2011). Ethical issues have been raised referring to the demand side of corruption (government), while the supply side of corruption (Sikka \& Lehman, 2015) has not received a significant amount of attention. Hence, by analysing an Italian episode of corruption in public procurement, our research focuses more on the actors rather than on the act of corruption (Everett et al., 2006)

The organization of this paper is as follows: Section 2 develops the theoretical concepts informing the analysis by framing the philosophical theories of Rousseau, Kant, Popper and others within the debate about anti-corruption strategies. Section 3 focuses on research methodology and the methods of analysis. Sections 4 and 5 provide the details of the case analysis; the final section presents the implications and conclusions.

\section{Theoretical framework}

Hoskin (2015) points out that the “'socio-political-economic-level" issue of "corruption prevention"' (p. 4) is inseparable from the problem of the construction of an ethical subject at the individual level. Accordingly, this paper suggests that when developing anti-corruption strategies, two intertwined questions should be considered. One question, as formulated by Popper, concerns the institutional mechanisms that define the structural dimension of corruption: 'How can we so organize political institutions that bad or incompetent rulers can be prevented from doing too much damage?' (Popper, 1966, p. 121). The second Platonic question focuses on the individual dimension: Who should rule? (Plato, The Republic).

In order to explain the implications of these questions for the determination of anti-corruption strategies, we can rely on the Rousseauian conceptualization of corruption and the theoretical insights provided by Kant and Popper on ethics and democracy. Rousseau's theory of the state helps us to better understand the phenomenon of corruption by showing how it is strongly related to the political processes that have led to the state's institution and to the ethical principles that are the conditions for the state's preservation.

In his work 'The Social Contract' (1762), Rousseau provides a normative version of the so-called social contract theory, a political theory that goes back to Plato and has been extended and reformulated in the work of philosophers such as Hobbes, Locke and Rawls. This theory addresses the question of the legitimacy of the state's authority and the origin of society by arguing that individuals' political and moral obligations are dependent upon an initial agreement (or contract) designed to establish the terms of the society in which they live.

According to this theory, the state is a moral community. The social contract establishes the ontological superiority of the community over the individual, and 'this act of association instantly replaces the individual person status of each contracting party by a moral and collective body' (Social Contract I: 6; emphasis added). It establishes an equality in the form of distributive justice among individuals that otherwise cannot be found in nature alone (Kateb, 1961; Mulgan, 1979). By entering into the social contract, individuals become citizens and establish a moral and collective body (state or sovereign) as an expression of the so-called 'general will' (Social Contract II: 3 ).

According to Rousseau, the general will differs from both the particular will and the will of all. This is especially clear when he says, 'The will of all is very different from the general will; the latter looks only to the common interest, while the former looks to private interest and is no more than a sum of particular wills' (Social Contract II: 3). The establishment of the general will implies both a sacrifice and a change; the individual, through the social contract, ceases to be a single individual and becomes a citizen as part of a community, thus sacrificing his purely individualistic and utilitarian concerns. Furthermore, as interpreted by Kant, it requires that the lawmakers promulgate the laws 'in such a way that they could have arisen from the united will of an entire people' (Kant, 1785, VI: 380f). Therefore, the respect of the 'general will' (Rousseau, 1762 ) is 'the touchstone of the legitimacy of every public enactment' (Kant, 1785, VI: 380f).

To be part of a moral community implies a shared conception of the common good, in the sense that 'what is good for me has to be good for someone who inhabits these roles. I inherit from the past of my family, my city, my tribe, my nation a variety of debts, inheritances, expectations and obligations' (MacIntyre, 2007, p. 220). The identity of the individual is embedded in the community to which he or she belongs, and so are his or her political and moral obligations.

Within this framework, corruption appears as a moral degeneration of both the state and the individual as an illegitimate exercise of power. Corruption occurs whenever:

... the prince came to have a particular will more active than the sovereign's, and employed the public force in his hands in obedience to this particular will [...] when the meanest interest brazenly helps itself to the sacred name of 'public good', when the general will falls silent [...] and wicked decrees directed solely to private interest get passed off as 'laws'. (Social Contract, III: 1) 
In this respect, Rousseau warns the citizens against the danger inherent in any form of political representation: the representatives may attempt to usurp the power that belongs only to the sovereign. Hence, Rousseau's normative theory recognizes a strong and direct form of democracy as the only mean to ensure the success of the social contract.

It therefore follows that where a mechanism of political representation exists, the preservation of the state is possible only when the sovereign people exercise some measure of control over the conduct of their rulers in order to ensure compliance with the social contract. As Popper (1966) suggested, an urgent question to ask in a representative democracy is the following: 'How can we so organize political institutions that bad or incompetent rulers can be prevented from doing too much damage?' (Popper, 1966, p. 121). The sovereign's power of control therefore becomes the last bastion of democracy:

Democracy, the right of the people to judge and to dismiss their government, is the only known device by which we can try to protect ourselves against the misuse of political power; it is the control of the rulers by the ruled. (Popper, 1966, p. 335).

The legitimacy of the executive power originates from the sovereign's capacity to limit it, modify it or take it back just as it wishes. It implies the accountability of rulers to the state and the sovereign, where by accountability we mean 'the relationship between an actor and a forum, in which the actor has an obligation to explain and to justify his or her conduct, the forum can pose questions and pass judgement, and the actor may face important consequences' (Bovens, 2010, p. 951). This accountability that ties the community to the government is a 'public accountability', where the term 'public' refers to the public sector so that the account is accessible to the citizens (Bovens, 2005). As highlighted by Bovens (2005), 'public accountability is not just the hallmark of democratic governance; it is also a sine qua non for democratic governance' (p. 192). We therefore suggest that corruption can flourish where these institutional arrangements do not operate properly, and it can become even worse where they are absent.

However, in order to understand the nature and the contents of this form of public accountability, the second theoretical question must be addressed: Who should rule? This question embraces an anthropology different from that of the agency theory underlining the previous one, as it assumes that each individual is a moral agent capable of acting in accordance with the demands of the moral law (Kant, 1785). Based on this perspective, public accountability involves the moral behaviour and ethics of the actors involved, and the legitimacy of political power ultimately rests on the citizens' abilities to censure unethical practices and wrong doings. Neither transparency nor the empowerment of civil society may be effective in a context where the notions of 'public good' and 'private interest' are devoid of meaning and absent in the cognitive schemas and value systems of the citizenship.

For Rousseau, morality is inseparable from politics, since 'all legitimate political obligations are in the last analysis moral obligations' (Noone, 1970, p. 4). The obligations of the rulers towards their citizens are moral and not simply legal. As Bovens (2010) clarifies, 'being accountable' is also ‘a virtue, a positive quality of organizations or officials' (p. 947) Accordingly, to give an account implies transforming 'one's efforts and exertions into a power that is subject to ethical evaluation' (Shearer, 2002, p. 544). Corruption therefore arises as a social phenomenon insofar as it concerns not just the individual but also the citizens as part of a moral community. In the words of MacIntyre (2007), 'I can only answer the question "What am I to do?" if I can answer the prior question “Of what story or stories do I find myself a part?"' (p. 216). In this respect, corruption consists in the lack of recognition of mutual duty and in a loss of a particular kind of autonomy.

The concept of autonomy developed by Rousseau is the same as the one that we can find in the work of Kant (Kateb, 1961). Both describe autonomy (from the Greek " $\alpha v \tau o$ $\varsigma$ " = self and $\nu$ ó $\mu$ o $\varsigma=$ law) as freedom or moral liberty (Cassirer, 1991), where freedom means acting according to a law that individuals have ascribed upon themselves: 'Autonomy of the will is the property of the will through which it is a law to itself (independently of all properties of the objects of volition)' (Kant, $1785, \mathrm{G} 4: 440$ ). Furthermore, Kant links the moral law and autonomy in contrast to heteronomy, the subjection of the will to some outside influence (e.g., natural impulses or inclinations) or to a consequentialist logic. Moral agency expresses the positive freedom of an individual whose will is self-determined and hence autonomous. However, this defence of autonomy does not result in a 'social atomism' (Wolgast, 1994, p. 1), but on the contrary, it helps to define the true conception of the 'social bond' (lien social), where 'such a bond must bind together freely acting persons, not dead things. Hence it cannot be something imposed upon the wills of these persons from without; they must constitute and create it themselves' (Cassirer, 1991, p. 31).

The Rousseauian concepts of autonomy and moral laws coincide with obedience to the general will; the individual, 'while uniting himself with all, still obeys only himself and remains as free as before' (Social Contract, I: 6), 'the general will being their will' (Social Contract, VI: 2). The will of an autonomous moral agent is both self-legislating and self-constraining, as the agent freely decides to be subject to the law that safeguards the public interest. It follows that it is in the obedience to laws that the citizens and public servants find their moral liberty and autonomy. The concept of autonomy is founded on the connection between the common good and obedience to the law, and the implication of this concept is twofold. First, the legitimacy of the law depends on it being an expression of the general will and on its effectiveness in enhancing the common good; otherwise, it becomes corrupt. Second, a citizen is corrupt when his will, losing its moral freedom, is determined by particular and individual purposes that conflict with the common good and laws. Hence, a public servant is autonomous whenever his behaviour conforms to the needs of the moral community to which he belongs. This moral drift facilitates the growth of corrupt networks. On this point, Rousseau warns against the possibility that public officials confuse the general will with a 'pseudo general will'. Although the "individual will" supplants "the communal self" in a corrupted person, these 
"small societies" will act as sort of a pseudo "general will" for the individual. [...] At this point the loyalty has been narrowed to the concerns of the faction, not the common good' (Dobel, 1978, pp. 964-965).

In connecting this theory to the anti-corruption debate, it follows that a prominent role should be given to the active participation of civil society-as it is in a direct democracy-in the evaluation of public programmes and in denouncing abuses of power, irregularities in the administration and corrupt practices. For example, the development of effective whistleblowing programmes and the enforcement of mechanisms that enable people to censure unethical practices may be a step forward in the right direction towards rectifying these problems. This approach that Everett et al. (2006) have termed 'the voice solution' (p. 6) has demonstrated positive results in countries such as Indonesia, Georgia and Colombia where, in addition to anti-corruption laws and integrity programmes, the 'popular mobilization against corruption' (Agere, 2000, p. 17) through the empowerment of outside agencies, NGOs and civil society has contributed to reduction of corruption (Klitgaard, 2014).

Three conditions are essential for this sort of model to be realized: (1) a simplification of the rules, (2) public access to information and (3) a sense of the state and appropriate civic behaviour. The latter requires that the virtue of autonomy should be possessed by public officials and citizens and have room to be cultivated and protected. In the context of public procurement, for example, it is crucial that public officials exercise their discretionary powers in the bidding process to serve the public interest (the general will). Anti-corruption measures such as the uniform, systemic and independent verification of conflicts of interest involving public officials and the requirement of transparency in asset declarations, public appointment processes and political party funding are measures that may enhance the autonomy of public officials. However, discretionary powers are sometimes unavoidable and at other times beneficial (e.g., it is not always the case in public tenders that the choice of the lowest bid responds best to the public needs), and the 'goodness' of the process ultimately rests on the ethics of the individuals involved.

\section{Methodology}

Our analysis empirically investigates the complex social phenomenon of corruption in order to translate the above theoretical explanations into practical insights.

In order to determine the most appropriate research methodology, we needed to consider the phenomenon to be analyzed, here corruption, more carefully. Our main assumption prior to further investigation was the following: corruption is nothing other than a practical problem of our society. As researchers approaching the phenomenon of corruption, we needed to start from our empirical and contingent experience of it. Our focus, then, was on praxis $(\pi \rho \tilde{\alpha} \xi \iota \varsigma)$.

Accordingly, we relied on case analysis research as the most valuable tool to investigate this complex phenomenon within its real-life context (Cooper \& Morgan, 2008; Yin, 2003). Quantitative methods have been adopted extensively when investigating corruption, but the translation of corruption into such variables 'draws attention away from the corrupt practices and the corrupt agent' (De Graaf, 2007, p. 41). Furthermore, there are not many studies on real life cases of corruption and, hence, more contingent and contextual research is needed (De Graaf, 2007). Case studies on corruption may also become valuable tools in teaching, as they help students to better understand the specifically human dynamics involved in corruption (Klitgaard, 1984).

This paper, therefore, focuses on a specific episode of corruption and attempts to describe the features of the corrupt practices in place in a specific context. In so doing, we acknowledge the 'primacy of context' (Flyvbjerg, 2004, p. 19), 'the priority of the particular' (Nussbaum, 1990, p. 37), and the 'force of example' (Flyvbjerg, 2006b, p. 228).

In terms of scientific validity, this 'bottom-up form of analysis' (Hoskin, 2015, p. 8) may lead to the conclusion that it is impossible to generalize from a single case. Relying on the Popperian scientific paradigm, Flyvbjerg (2004) concludes, 'the case study is ideal for generalizing using the type of test [...] called falsification' (p. 227). Our analysis contributes to this ongoing debate by suggesting that the main purpose of case study research is not to generalize, but instead to enhance a particular science for applied thought through the exercise of a practical reasoning.

Developing this type of practical approach involves providing a case analysis that sheds light on the behaviours and values of the actors involved by framing what Flyvbjerg (2004) has defined as 'situational ethics' (p. 11). The latter require observation of both the moral will and the moral skill of the actors. In other words, 'People with practical wisdom have the moral will to do the right thing and the moral skill to figure out what the right thing is in any particular situation' (Schwartz, 2011, p. 3). Therefore, our analysis investigated how corruption occurs in the present by providing a relative perspective, and the final goal was not to generalize from a specific episode, but instead to effectively describe a praxis in order to produce a 'practical truth'.

Indeed, practical knowledge is contingent and consequently it can be obtained only by discovering what is practically true, or 'a truth created by action' (Anscombe, 1999). As Flyvbjerg (2006b, p. 238) explains, 'The case study is itself the result ... the narrative itself is the answer'. The production of practical truth implies the contextualization of the assumptions that underline the theoretical framework described above. In other words, 'To restore to practice its practical truth, we must therefore reintroduce time into the theoretical representation of a practice which, being temporally structured, is intrinsically defined by its tempo' (Bourdieu, 1977, p. 8).

Therefore, the description of the case allows for further exploration of the relationship between the public officials' corrupt behaviour and the mechanisms of public procurement that define their space of action and power in a specific time. In addition, the production of practical truth has an important implication for what the mission of research should be. As Marx once said, 'All social life is essentially practical. All mysteries which lead theory to mystics, find their rational solution 


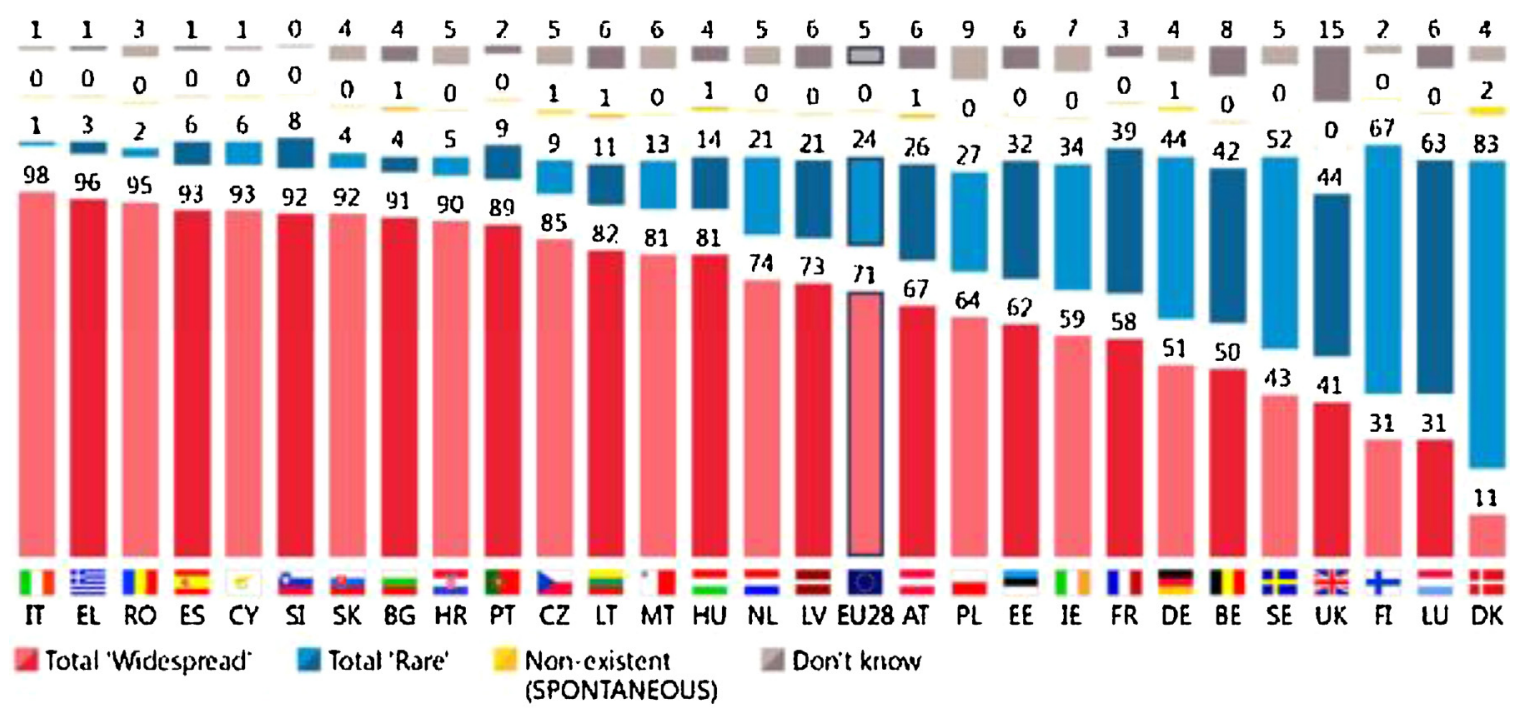

Fig. 1. Survey question: How widespread do you think the problem of corruption is in your country? (\%). Source: Eurobarometer TI (2015).

in human practice and in the comprehension of this practice' (Marx, 1845, VIII). In accordance with this view, the case study developed here attempts to 'articulate and explore the conflicts about values, interests, and the operation of power' (Cooper \& Morgan, 2008, p. 164).

The ultimate goal of our case description was to comprehend and analyze the practice of corruption in the hopes that this could lead to practical solutions. By doing so, this article contributes to phronetic organization research (Everett \& Tremblay, 2014; Flyvbjerg, 2006a) that has its foundations in the Aristotelian concept of practical wisdom.

To convey the complexity of the phenomenon, we drew from many sources of data, including judicial documents, government records, and newspapers articles. The aim of the analysis was not to reconstruct a complete, exhaustive, and objective description, but to develop an interpretative understanding of the corrupt practices in their individual and structural dimensions, letting the case unfold into other fruitful insights (Flyvbjerg, 2006b).

\section{Corruption and anti-corruption strategies in Italy}

As emphasized by Della Porta and Vannucci (1999), 'the Italian case can [...] be considered as a sort of magnifying glass for the analysis of more general patterns of corruption in democratic systems' (p. 13). When it comes to perceived levels of corruption, Italy ranks in 61st place together with countries such as Senegal, South Africa and Montenegro (Transparency International, 2015), and second to last in the rank of EU countries, followed only by Bulgaria. Similarly, the World Bank's Control of Corruption Index (2013) places Italy at the bottom of European rankings. According to the 2015 Eurobarometer, $98 \%$ of respondent companies in Italy say that corruption is widespread in their country, compared to $11 \%$ of those in Denmark (see Fig. 1). In particular, 76\% of respondents believe corruption in public procurement as managed by national authorities is widespread (see Fig. 2). Overall, the Italian culture emerges as 'alienated, fragmented and particularistic, with low trust in politics and public administration' (Della Porta \& Vannucci, 2005, p. 6).

However, despite these numbers, the Italian judicial statistics indicate a downward trend in the number of people convicted for corruption from 749 in 2007 to 458 in 2011 (ANAC, 2013). These data suggest an inverse relationship between the corruption practised and the corruption reported and punished (Ministry of Interior, 2012).

In 1992, the Bribesville (Tangentopoli) scandal did not seem to function as a trigger for radical change, as was expected (Barbacetto, Gomez, \& Travaglio, 2012; Sargiacomo et al., 2015; Vannucci, 2009). In the aftermath of the scandal, several corruption-enhancing measures were proposed instead (Law n. 367/2001; Law n. 248/2002; Law n. 140/2003; Law n. 241/2006; Law 124/2008). Hence, some critical facilitators for corruption remained in place, including the following: (1) an ineffective time limit in the statute of limitation, (2) a lack of a clear and enforceable conflict of interest standards, (3) difficulty in accessing public information, (4) a general lack of transparency, (4) a lack of effective codes of conduct and (5) the complexity and fragmentation of the legal framework (GRECO, 2008; Transparency International, 2011b). Furthermore, from 2003 to 2014, three different anti-corruption authorities were appointed and their lack of authority and independence, excessive bureaucratization, and lack of resources and powers jeopardized the effectiveness of the corruption control measures (ANAC, 2014; GRECO, 2008; L'Espresso, 2008; OECD, 2013a). Law 190/2012 (the so-called 'Severino's law') and the recent Law 69/2015 seem to address many of the criticalities highlighted above (e.g., by increasing the statute of limitations and empowering anti-corruption authorities), but corruption still appears to be widespread, as the recent Expo 2015 and Mafia Capitale scandals seem to confirm. 


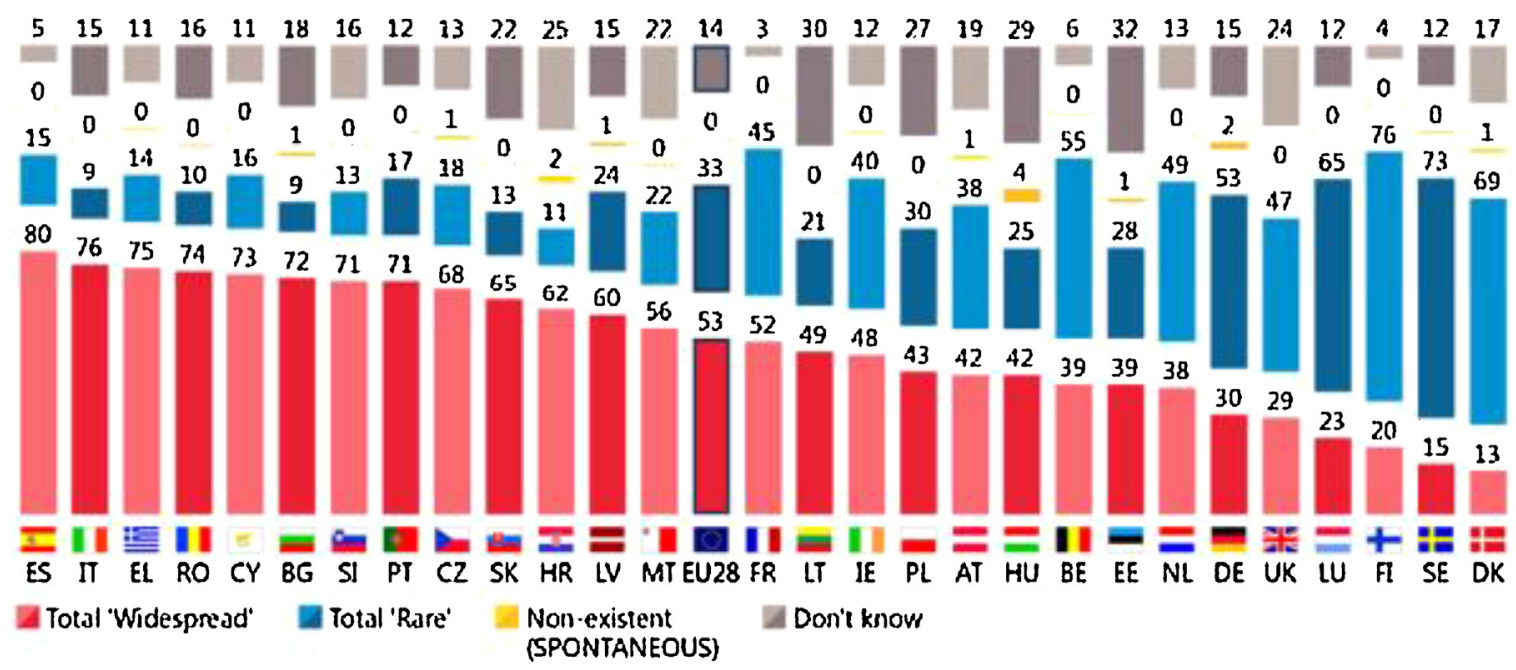

Fig. 2. Survey question: How widespread do you think corruption in public procurement managed by national authorities is in your country (\%)? Source: Eurobarometer TI (2015).

With respect to public procurement, several measures have been adopted to enhance the transparency and efficiency of these processes (Legislative Decree 163/2006; Law n. 136/2010; Law 190/2012), such as the establishment of centralized purchasing bodies, the obligation on prefects to compile 'white lists' of economic operators and the development of eprocurement mechanisms. Nevertheless, for large public works alone, corruption (including indirect losses) is estimated to amount to as much as $40 \%$ of total public procurement value (EU Anti-Corruption Report, 2014a). Among the reasons for these numbers, there is the impossibility for the Court of Audit to carry out checks during the process without advance warning, and the consistent use of negotiated procedures, in particular without publication of contract notices (in 2010, such cases accounted for $14 \%$ of value of contracts, compared to the $6 \%$ of the European average) (EU Anti-Corruption Report, 2014a). As a result, despite these attempts to address corruption, 'reducing corruption and improving trust must remain a priority' in Italy (OECD, 2015, p. 4).

\section{An Italian case study}

The analysis of an Italian case study allows us to investigate the dangerous combination of democracy with high levels of corruption that characterizes this specific setting (Colazingari \& Rose-Ackerman, 1998). We focus here on a specific episode of corruption in public procurement. The case analyzed is a specific episode within a broader corruption scandal, the ' $G 8$ and big events scandal' that dominated the national press in 2010 and had a significant impact on public opinion. The scandal involved a broad range of actors, including business people, politicians and public officials, and it was generally considered to be one of the biggest Italian scandals after the Bribesville scandal of the early 1990s. Due to the complexity and dimension of the scandal, one paper cannot be expected to cover the totality of the issues involved. To complicate things even further, the judicial process is still ongoing, so there are risks with respect to maintaining the accuracy of the narrative. Therefore, we have chosen to focus only on a specific episode of this scandal: the first episode that triggered the entire court proceedings and the only one for which convictions have been obtained (Il Fatto Quotidiano, 2016).

It should be noted that the selected case encompasses all of the elements that allow corruption to occur and flourish in the Italian context. In addition, it is particularly interesting because it confirms the permeability of public procurement to corruption (Neu et al., 2015) and sheds light on the ethical issues raised by inter-organizational relationships (Osborne, 2010). Furthermore, this specific case shows the limitations of both the legalistic and the neoliberal approaches to corruption.

In a decision delivered on 31 October 2012, the Court of Rome returned a guilty verdict, according to which two public officials, Angelo Balducci and Fabio De Sanctis, had sold their political influence to Riccardo Fusi and Roberto Bartolomei, managers of the Italian company Baldassini Tognozzi Pontelli (BTP), in exchange for private benefits. The issue at stake was the contract for the construction of a police academy in Florence, and other contracts for costly public works such as the building tenders of so-called 'big events' (the celebration of the 150th anniversary of Italian unification and the G8 Summit).

The legal inquiry into the case began in 2007, while the press only discovered it in 2010 . Only in 2016 was a final verdict reached in court (see Table 1 for a synthesis of the milestones of the case). The starting point of the inquiry involved the unearthing of some conversations between Vincenzo Di Nardo, CEO of BTP, and some of his colleagues and friends. BTP had just lost three contract bids for major infrastructural works related to the celebration of the 150th anniversary of Italian unification: (1) the construction of the Florence Music and Culture Park, (2) the realization of the Cinema Palace at the Venice Lido, and (3) the completion of the Perugia-Sant'Egidio International Airport. 
Table 1

Case timeline.

\begin{tabular}{l}
\hline The legal pathway \\
The Ministry of Infrastructure and Transport awards the contract \\
for the police academy (Florence) to BTP. \\
10 days after entering the construction site, BTP asks for \\
adjustment of the seismic coefficient to higher levels (from $\langle 1\rangle$ to \\
$\langle 1.4\rangle$ ), while denouncing the necessity of changing the initial \\
project. It is the start of a long controversy with the Ministry. \\
BTP asks for an arbitration award. \\
The Ministry of Infrastructure and Transport reassigns the contract \\
to the rival company Ansaldi as a result of breach of contract. \\
BTP obtains the benefit of the arbitration award and EUR \\
$34,410,061$ in compensation from the Ministry. \\
The attorney general asks the superior court in Rome for \\
suspension of the enforceability of the arbitration award.
\end{tabular}

$9 / 28 / 2001$

$4 / 2 / 2004$

$3-4 / 10 / 2005$

$03 / 2006$

$7 / 27 / 2007$

$11 / 6 / 2007$

1/23/2008 Rome. First meeting between Di Nardo, De Vito Piscicelli, and De Sanctis.

2/1/2008 Rome. Meeting between Fusi, Di Nardo, De Vito Piscicelli, Balducci, and De Sanctis.

2/13/2008 Rome. Meeting between Fusi, Bartolomei, De Vito Piscicelli, Balducci, and De Sanctis:

Discussion about the possibility of reassigning the Police academy contract to BTP.

Fusi and Bartolomei are invited to express their preferences on contracts that are going to be awarded for the celebration of the 150th anniversary of Italian unification.

2/18/2008 Florence. Meeting between Fusi and De Vito Piscicelli. De Vito Piscicelli proposes the pactum sceleris to Fusi: the public officials promise to award contracts to BTP concerning the works for two "big events" and to reassign to BTP the contract for the Police academy in exchange of money and other utilities.

Balducci resigns from the office as head of the Test Committee for

$3 / 7 / 2008$ the Police academy.

7/30/2008 The politician Denis Verdini gets in contact with Balducci thanks to the intermediation of Fusi. Verdini exercises his political influence over the party colleague Matteo Matteoli, Minister of Infrastructure and Transport.

$10 / 10 / 2008$ $12 / 2008$

The Minister Matteoli promotes De Sanctis as special commissioner of a Commission for the Resolution of the Police academy controversy.

De Sanctis is appointed as Administrator of Public Works in the regions of Tuscany, Umbria and Marche.

Transfer of powers and duties from the Ministry of infrastructure and Transport to the Administrator of Public Works in the Tuscany region (De Sanctis).

The company Astaldi receives the order to stop the works in the construction site.

Source: Own elaboration.

Di Nardo seemed sure that Angelo Balducci, the head of the Department for the Development and Competitiveness of Tourism, had manipulated all of the bid selection processes:

I realized that there is a kind of lobby group of Roman people living in the Ministries. [...] They are bandits ... sooner or later the newspapers will report that they have been caught with a bribe in hand... (pre-trial detention order, p. 78).

These are violent people [...] I didn't know this team of Balducci ... this is a task force, cohesive, solid ... they are bulldozers (pre-trial detention order, p. 326)

At the end of 2007, Fusi, a patron of BTP, had become aware that he was involved in an environment in which other entrepreneurs illicitly influenced the main decision-makers of the state. He later explained to the judges, 'The law of 2006 gave enormous discretionary powers [...] Balducci understood this mechanism and he was the man more courted and revered in Italy' (Imarisio, 2010). The Public Procurement Code of 2006 (Legislative Decree n. 163/2006) established that public contracts may be awarded on the basis of either the lowest price or the economically most advantageous (value for money), therefore providing the contracting authority with wide discretionary power on public procurement. The same year, Law 286/2006 instituted the Department for the Development and Competitiveness of Tourism at the Presidency of the Council of Ministers. Specifically, the Department was in charge of managing the bidding processes for so-called big events. 
Before 2001, the notion a 'big event' referred only to extraordinary events such as natural disasters that required the institution of a state of emergency. Law 401/2001 extended this notion to other types of events. In 23 November 2007, a Decree of the President of the Council of Ministers declared the complex of works related to the celebration of the 150th anniversary of Italian unification to be a 'big event'. In September of the same year, the G8 Summit had also been declared a 'big event'. Such declaration is important because it involves the institution of a state of emergency and implies the application of a special regulation. Briefly, this regulation establishes a concentration of power in the hands of the Presidency of the Council of Ministers, with more flexible rules of procedure notwithstanding the current regulations in addition to diminished financial restrictions.

In 2007, a Decree of the President of the Council of Ministers established a 'Structure of Mission' at the Department for the Development and Competitiveness of Tourism for the organization of the celebration of the 150th anniversary of Italian unification. The President of the Council of Ministers designated Angelo Balducci as head of the Structure and the public official Fabio De Sanctis as a delegate commissioner (pre-trial detention order, pp. 70-71). In this new context, the two public officials had so much power concentrated in their hands that they were defined by De Sanctis as having a 'license to kill'. According to De Sanctis, 'We can say ... how to say ... we have a license to kill ... we can grab all we want' (July 01, 2008; pre-trial detention order, p. 4).

At that time, the major concern for BTP management was the reassignment of the contract for the building of the police academy in Florence. In 2001, the Ministry of Infrastructure and Transport awarded the contract for this work to BTP. However, in 2006, the contract was reassigned to the rival company Ansaldi as result of a breach of contract. In response, the management of BTP decided to bring a lawsuit against the Ministry in order to get back the contract. In September 2007, BTP obtained the benefit of an arbitration award, but the latter did not establish the right of BTP to regain the contract. On 3 October 2007, the Ministry impugned the arbitration award. At the end of the year, BTP management decided to undertake illegal action to reverse the situation in favour of BTP. The only possible way to do this would have been to access the network system of public procurement managed by Angelo Balducci (La Repubblica, 2013).

The key actor who made this possible was Francesco Maria De Vito Piscicelli, a small businessperson with many useful relationships in the palaces of power in Rome, and a long-standing relationship with the two public officials. In order to take advantage of his political connections, Fusi decided to start a business relationship with the Opere pubbliche e ambiente s.p.a. (Public Infrastructure and Environment), the small economically devastated company managed by De Vito Piscicelli. Solicited by Di Nardo, De Vito Piscicelli organized many meetings between the public officials, Fusi and Bartolomei. Beginning on 23 January 2008, these actors met each other many times. On the first of February 2008, a pactum sceleris was finally signed (pre-trial detention order). The object of the corrupt exchange was the following: the public officials promised to award BTP the contracts concerning two 'big events' (the 150th Anniversary and the G8 Summit) and to reassign the contract for the police academy to BTP in exchange for money and other utilities.

Although Fusi already had two lawyers working on the issue of the police academy, the public officials provided him with their own lawyer, Guido Cerruti, 'as if it was not important if he worked for the public administration or for the interests of the private [provider]' (the verdict document, p. 50). In so doing, the two public officials decided to take the part of the private provider in the arbitration that was opposing BTP against the public administration. It soon became clear that the bribe was part of the money given to Cerruti as 'payment' for legal counsel. The pactum sceleris was to involve not only an exchange of money, but also the distribution of other utilities. Indeed, Fusi was aware that the reassignment of the police academy contract depended on the concentration of power in the hands of the public officials.

At that time, Balducci was the head of the Test Committee for the police academy, but he and De Sanctis did not have any decision power over the contract for the academy. However, thanks to a deep network of relationships, the two public officials soon succeeded in obtaining power to manage the awarding of the contract. Fusi provided the two public officials with the political protection of a powerful, reliable friend and business partner, the politician Denis Verdini, coordinator of the government's political party (Corriere della sera, 2016). Verdini could then exercise his political influence over party colleague Matteo Matteoli, Minister of Infrastructure and Transport.

In 2009, as result of this sphere of political influence, the public official De Sanctis was promoted to the position of administrator of public works in the regions of Tuscany, Umbria, and Marche, despite his not having the necessary professional qualifications. At the same time, the Minister of Infrastructure and Transport promoted Balducci to be chairman of the Board of Public Works. It was soon clear that these promotions were made to resolve the issue of the police academy in favour of BTP. In fact, thanks to the commitment of Balducci in his new role, in February 2009 De Sanctis won the responsibility of managing the police academy's contract that had been transferred from the Minister of Infrastructure and Transport to the Agency of Public Works, now chaired by him.

Between April and October 2009, all of the terms and agreements of the pactum sceleris were set to be accomplished; Astaldi received the order to stop work on the construction site, and complex administrative machinery was set up to allow for the reassignment of the contract to BTP. Suddenly, however, the judiciary intervened.

\section{Discussion}

This case shows how the lack of public control over government practices and the lack of autonomy of public officials establishes an 'accountability gap'. Several elements were aligned in order to facilitate the occurrence of corruption: (1) the concentration of unlimited discretionary power in the hands of a few people, (2) the lack of transparency in the appointment 
of public officials, (3) the collusion between controllers and the controlled, (4) the complexity of the legal process, (5) the length of judicial proceedings and (6) the lack of a sense of the state and appropriate civic behaviour.

The complexity of the normative framework allowed for the two public officials, Balducci and De Sanctis, to act "behind the lines', thus allowing for the concentration of enormous discretionary powers over public procurement in their hands without being subject to any authoritative control, neither that of civil society nor that of the judiciary. Balducci and De Sanctis were in charge of identifying the providers to which they ought to award the contracts, and they could select any necessary professional and determine the procedural measures. Quite simply, 'Balducci had carte blanche to use his companies ... to use what he wanted and, in practice, to avoid the public tender' (words of the architect Casamonti, pre-trial detention order, p. 326). Furthermore, the way in which the political influence of Verdini affected the appointment processes of Balducci and De Sanctis (the latter elected without having the necessary professional qualifications) shows a lack of transparency and meritocracy in the selection of public officials.

This great and pervasive power free from accountability was very much a source of corruption in this case. As noticed by Roberts (2015), the attraction of corruption consists in the exercise of a quasi-sovereign power within hierarchy. This power is the sovereign power of the community and the illegitimate appropriation of this power by public servants indicates a lack of democratic accountability as defined by our theoretical framework.

The production of derogations from conventional norms coexisted with stringent anti-corruption rules and controls (Sargiacomo et al., 2015). However, the discretionary power exercised by the actors allowed them to bypass these rules in the name of simplification and emergency. In this respect, the actors deployed the complexity of the rules and the red tape as a justification for acting against the current regulations. Interestingly, Fusi used the same argument: the red tape would have (and actually had) slowed down the judicial process, hence the illegal way was the fastest way to obtain what he believed was rightfully his. This consideration shows how a fragmented and excessively complex legal framework can create the conditions for the moral justification of wrongdoing. The public officials made instrumental use of the laws, which become tools for transforming otherwise illegal and unethical behaviours into legitimate practices. In other words, in such a process, 'first, they consider the needs of the private briber and then they make a search for technical-juridical considerations to satisfy the interests of the private actor' (the verdict document, p. 83). It is precisely the actors' knowledge of the rules and procedures of power that allows them to construct a corrupt network (Roberts, 2015).

In a system where democratic control is weakened through a long chain of delegations, public officials are not forced to account for violations of the social contract, and neither are the business actors (Papadopoulos, 2007). Consequently, such violations become widespread practice among the procurement actors (bureaucrats, politicians, and entrepreneurs) that can advantage from them. In such a situation, the contract of corruption gradually takes the place of the original social contract. The corrupt rules obtain legitimization through the progressive adhesion of the actors to the 'prevailing models of behaviour' (Della Porta \& Vannucci, 2005, p. 16). In 13 June 2010, in an interview for a national newspaper, Fusi stated, 'I am a victim of a general behaviour. In Italy, the system of public procurement works in this way, everybody knows this. It is well known and accepted by all the participants...' (Imarisio, 2010). As explained by Neu et al. (2015), 'procurement participants [...] are also very much subjected to and constructed as subjects by their own practices and the practices of others' (p. 11).

In the Italian context, the 'moral cost of corruption' (Della Porta \& Vannucci, 2005, p. 14) is very low, as there does not seem to exist a value system that holds corruption to blame. Hence, corruption occurs not as a single isolated episode, but as the expression of a broader, complex, and holistic situation. It becomes a normal modus operandi, where 'wide, pronged and unfair advantages are pursued, and an illicit relationship is strengthened along the time implying the engagement in every future and next contract' (Corriere Fiorentino, 2010).

In this respect, there was a meaningful conversation between two architects, Marco Casamonti and Paolo Desideri, who were involved in the bidding process for the 150th anniversary of Italian unification:

Casamonti: Italy is a country where, actually, things do not go in the right way ... this is a general condition ... today is my turn, tomorrow is yours ... things do not go in the right way because the interference of politics assumes shameful tones that ... in my opinion ... fall outside quality ... and, second, because the management of the Ministry of Public Works is not so transparent $[\ldots]$

Desideri: [...] there is no doubt that the companies refer to an incubator for the acceptance of their candidacy .... it is not the incubator within which we operate that is cultural [...]

Casamonti: [...] there is a system in the Ministry of Public Works ... that in my opinion it is almost a scandal...

Desideri: [...] they are immersed in a gelatinous system... (pre-trial detention order, p. 326).

The most dangerous implication of this 'gelatinous system' is the actors' perception that it is impossible to act outside of it. The market so created has high barriers to entry and exit (Della Porta \& Vannucci, 2005). The exclusion from this system implies the impossibility for social actors to participate in an ethical economic life, since '... it is a race to gain the favours of the public officials who can decide your life' (words of Fusi, Imarisio, 2010).

The private and public spheres overlap, thus becoming almost indistinguishable. The loyalty to the common good is sacrificed in the name of the mutual benefits that the pactum sceleris would bring to all of the contractors. The economic obligations to the participants of the corrupt network replace the social obligations to the community. The bidding 
processes are conducted not by looking at the common good (expressed through the general will), but by considering the private interest of a few people (e.g., the interest of BTP to regain the contract and the utilities gained by the two public officials). As a result, the law itself becomes corrupted and there is a dangerous relegation of the general will to a 'pseudo general will'. In this specific case, the Legislative Decree n. 163/2006 and several other decrees on big events, rather than enhancing the autonomy of the public officials (as was maybe the genuine intent of the law), allowed them to use the conferred discretionary powers to pursue their own interests while at the same time 'respecting' all of the rules.

The events described suggest a radical loss of identity and autonomy among the public administration (the verdict document, p. 23). Indeed, the public officials seem to be acting in the grip of interests that are sometimes indistinguishable from those of the private corrupters. On this point, the press reported an 'emblematic phone call between the controller De Sanctis and the controlled Fusi. The latter congratulates De Sanctis for his promotion; De Sanctis thanks him. And concludes: "I am working for you although it is the 31st of December"' (La Stampa, 2010).

This conversation dramatically reveals how the logic of competition and private profit was permeating public administration fusing its mission with the interests of the private suppliers. The public officials evaluated the 'goodness' of their actions based on whether these actions might provide utility for the corrupt network of participants. This privatization of moral concerns also emerged where the decisions of the actors seemed to be guided by the considerations of public interest. For example, the promotion of De Sanctis as administrator of public works in Tuscany, far from being conceived of as an opportunity for enhancing the public interest, was a further expression of the enslavement of the two public officials to the interests of Fusi and his company:

There is the possibility that I become ... we can say the Administrator of Public Works in Florence ... (laugh) ... you understand ... the first issue that we have to deal with will be for sure the Marshals. (De Sanctis to Fusi; pre-trial detention order, p. 47)

Similarly, Balducci decided to resign as head of the Test Committee for the police academy because it was beneficial for the development of solutions in favour of BTP. De Sanctis clearly expressed this point in a conversation with Fusi where he says, 'Yes, yes ... he (Balducci) will sign as soon as possible the resignation ... tomorrow he is going to sign ... understand? [...] So I read it to you and I leave a seed ... a very important seed ...' (pre-trial detention order, p. 116).

Furthermore, subsequent contract modifications related to the seismic coefficient of the structures under construction were not evaluated in consideration of the public safety, but were instead viewed as an opportunity to inflate the costs of the contract and gain more profit:

He (De Sanctis) can also review and update the prices ... this is not something that you can easily obtain ... have you got it? ... he was neither thinking to ask for it ... I do not know if I was clear enough... (De Vito Piscicelli to Gagliardi, pre-trial detention order, p. 37)

As noted in the EU Anti-Corruption Report (2014a), sometimes 'the public procurement process is proper, procedures are respected, and winning bids indeed seem to be the most advantageous, but in contrast, the quality of deliverables is intentionally compromised in the execution phase' (p. 12). Again, the formal correctness of the procedures is used as a device for hiding corrupt practices. In all of these episodes, the particular and individual purposes that conflicted with the common good determined the will of the actors, regardless of (and despite) the legality of their actions.

This case shows that corruption is more about the conscience and ethics of the actors. In this respect, it is significant that we find the same actors operating in analogous episodes of the 'G8 and big events scandal'. Consider, for example, the following conversation between De Vito Piscicelli and his brother-in-law Gagliardi in the aftermath of the L'Aquila earthquake:

Gagliardi: Stay on this earthquake thing down there [at the Office of Public Works] because we've got to be ready to start up quickly, there's not an earthquake every day.

De Vito Piscicelli: I know (laughing).

Gagliardi: I'm just speaking for the sake of speaking ... poor people, right?

De Vito Piscicelli: Yes sure ... I was laughing in my bed this morning at 3:30 [when the quake happened].

Gagliardi: Yes, so was I ... Ok, bye.

This conversation shows that De Vito Piscicelli was at the centre of a broader corrupt network that, expanding gradually, continued to embrace new actors and new corrupt deals, and sadly including those concerning the resources devoted to reconstruction after the L'Aquila earthquake in 2009. Only by following the actors was the judiciary able to unveil the plot of corrupt networks.

In this corrupt environment, the engineer Benedetto Mercuri, the officer responsible for tenders (RUP), raised some concerns about the pertinence of the decision made by De Sanctis in stopping the work:

There, there are 350 workers that will be laid off ... they stop the machineries ... they stop the subcontractors ... and the plants that are producing the prefabricated components ... with all the mess going on today ... that people do not have a job, do not have nothing [...] Those are 350 workers ... families [...] I realize everything ... the pressures [...] I do not want to do this work anymore ... you must dismiss me. (pp. 56-64, pre-trial detention order) 


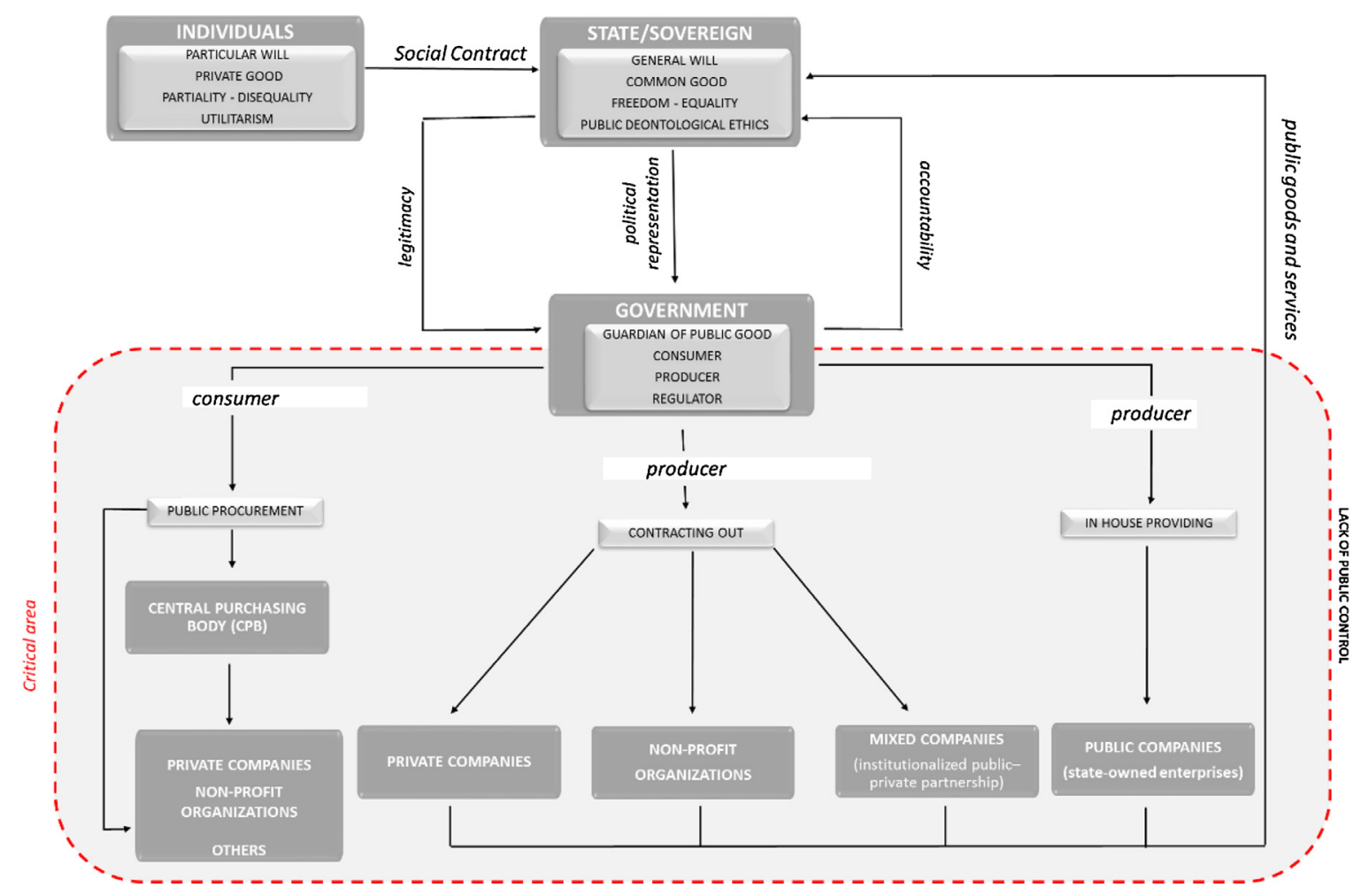

Source: Own elaboration.

Fig. 3. The role of the state in modern democracy.

The quotation reveals an understanding of the common good that lay dormant in some of the public official's consciences. Despite his position as a subordinate in the hierarchy of power, Mercuri resists the internalization of the desire of the powerful' (Roberts, 2015, p. 5) and tries to challenge the corrupt conduct of his superiors by calling for accountability.

Mercuri would be dismissed from his role, but soon the main actors of this history of ordinary corruption would be required to account for their actions in front of the judiciary as well as in front of the citizens, the original contractors of the broken social contract.

\section{Conclusions}

The case analyzed shows that corruption concerns the ethics of the individual and the capacity of society to unveil and condemn corrupt behaviours. It concerns both the people's virtue of recognizing corruption as an immoral behaviour and hence condemning it, and their 'capability' (Sen, 1999, p. 75) to exercise their control on the actions of the rulers. These aspects define the sphere of what we have defined with the term 'public accountability'.

In the Italian episode, the actors used the laws to hide corruption behind the formal correctness of the rules (e.g., Law $401 / 2001$ on big events) and the complexity of the law legitimized rather than prevented recourse to alternative illegal ways of action (Barbieri \& Giavazzi, 2014). Furthermore, the episode confirms that the overlapping role of the state as both consumer and regulator can lead to situations where 'politicians and bureaucrats are responsible for operationalizing the very rules and regulations that will govern their subsequent behaviours' (Sargiacomo et al., 2015, p. 7). The paradoxical result is the contradictory role of the state that nourishes the corruption it should eradicate, and a government that is playing a double role of controller and controlled. In this respect, the case of Italy offers an emblematic example among others of a formal legal and democratic framework coupled with a widespread lack of accountability.

In addition, the practice of public procurement, invoked by the neoliberalists, facilitated the spread of corruption because the multiplicity and heterogeneity of the agents involved made public control more complex (Soudry, 2007). A complicated network of governance weakens the public accountability that links citizens to their political representatives by strengthen the power of private actors through marketing practices. Bureaucrats take on the role of agents for politicians who in turn act as agents for the electorate (Murray, 2009). This long chain of delegation transforms shared responsibilities between multiple actors (private and public) into a diffused lack of responsibility by increasing 'the number of actors who are involved in the policy process without being democratically authorized ex ante, and without being subject to democratic control ex post' (Papadopoulos, 2007, p. 476). As a result, the decision-making processes become opaque (Papadopoulos, 2007; Thompson, 1980), thus opening the way for corruption. 
In summary, the novelty of the corruption portrayed in our analysis consists in two main characteristics. First, in response to the shift from government to network governance, corruption itself becomes a network (or an expression of a 'pseudo general will') that increasingly relies on the intermediation of business actors (e.g., De Vito Piscicelli) (Della Porta \& Vannucci, 2007; Neu et al., 2013) and uses the complexity and opacity of legislation and governance to its advantage (Sargiacomo et al., 2015). Corruption results in a loss of steering capacity (Graycar \& Villa, 2011), and the inability of governance to enhance democratic control leads to even more corruption (Kotera, Okada, \& Samreth, 2012). Hence, a neoliberal approach to the problem may exacerbate rather than mitigate the corrupting effect of institutionalized relationships between private and public actors in the public procurement context. Indeed, the private actors and the bureaucrats play an important part in the process of delivering public services without being required to be accountable to the citizens (Crouch et al., 2000). Therefore, the traditional idea of political accountability is not functional anymore for democratic empowerment, and there is a need to broaden the accountability process by giving voice to civil society and more power to the judiciary. This involves a simplification of the rules and more transparency.

The anti-corruption measures introduced by top performing countries such as New Zealand, Finland, and Sweden (e.g., comprehensive systems of e-governance) may offer valuable insights in this respect. In Denmark, for example, political parties devised an agreement called the 'openness scheme' that invites public servants to declare information such as gifts received, monthly spending, and travel expenses (European Commission, 2014c; Transparency International, 2011a). In Finland, the Parliament's website reports the notifications of interest ('disclosure of outside ties') that the Members of Parliament (MPs) are required to file at the beginning of each parliamentary term (European Commission, 2014e; Transparency International, 2011a). In Sweden, the government provides extensive information on the details of its budget and financial activities during the budget process, therefore allowing citizens to exercise some control over the management of public funds (European Commission, 2014d; Transparency International, 2011a, 2011b).

Second, new public corruption refers to the case of individuals lacking the virtue of autonomy who are provided with enormous discretionary power (e.g., Balducci and De Sanctis). By focusing on the macro dimension of the phenomenon, policy makers and scholars risk neglecting the centrality of the Platonic question: Who should rule? This question points to the subject of corruption and to the necessity of 'more inherently moral people' (Everett et al., 2006, p. 7). In this respect, if the case analyzed had contained clear and simple rules, the publicity of the appointment procedures could have ensured a fairer evaluation of the autonomy of the actors appointed.

Our analysis reveals the weakness of the legalistic/control approach. In other words, anti-corruption measures (such as those described above adopted by northern European countries) count for little if a culture of public ethics is not widespread. The virtue of autonomy requires that public servants internalize the moral law of mutual duty and understand their role and mission in the moral community. In this respect, the case of Denmark, at the top of Transparency International's Corruption Perceptions Index (Transparency International, 2015), is emblematic of a case where, due to a 'tradition of high ethical standards and transparency in public procedures, few formal rules regulating integrity and anti-corruption are in place in the public administration' (EU Anti-Corruption Report, 2014c, p. 3).

Overall, this paper confirms the conclusions of previous critical accounting studies that have described "the "doubled" nature of corruption in which processes designed to protect the public interest are mobilized by the corrupt for their private purposes' (Roberts, 2015, p. 2; Sargiacomo et al., 2015). In particular, the case offers an example of 'the use of the law to evade the law' (Hoskin, 2015, p. 2) and points to the weakness of anti-corruption assemblages in contexts where the supply-side of corruption fall outside of the public's control (Sikka \& Lehman, 2015), as is the case with public procurement. Furthermore, our research adds to those studies that have examined anti-corruption discourses and strategies (Everett et al., 2006; Everett, Neu, \& Rahaman, 2007) by showing the limitations of the legalistic and neoliberal approaches to corruption. Along with Johnston (2015), we therefore stress the need of involving civil society in corruption control.

However, the major contribution of our research lies in the attempt to understand the phenomenon of corruption in light of the concept of 'public accountability'. By understanding this concept in terms of Rousseau's theory of the social contract, we have highlighted the intertwined relationship between the virtue of autonomy (to be accountable) and the intersubjective and political meaning of democracy (to be held accountable) at the centre of what we have defined as 'new public corruption'. As a result, some 'old' questions have proven to be useful for understanding the contemporary face of corruption and the validity of modern managerial practices.

Due to the complexity of the phenomenon of corruption, the primary limitation of this study is that it focuses exclusively on state intervention in consumption and does not provide an analysis of other domains, such as the direct production of goods and services (see Fig. 3).

Certainly, a valuable contribution to the comprehension of the phenomenon may, for example, derive from the analysis of corruption as it occurs within the context of private-public partnership and state-owned enterprises. However, this limitation points beyond the scope of the present paper to directions for future research on the role of corruption in public management.

\section{References}

Agere, S. (2000). Promoting good governance: Principles, practices and perspectives (Vol. 11) Commonwealth Secretariat.

Agranoff, R. (2008). Intergovernmental and network administration, accountability, and performance: Symposium introduction. Public Perform. Manag. Rev., 31(3), 315-319. 
Almquist, R., Grossi, G., van Helden, G. J., \& Reichard, C. (2013). Public sector governance and accountability. Crit. Perspect. Account., 24(7-8), 479-487.

Anscombe, G. E. M. (1999). Practical truth. Logos, 2(3), 68-75.

Argyriades, D. (2010). From bureaucracy to debureaucratization? Public Organ. Rev., 10(3), 275-297.

Bayley, D. H. (1966). The effects of corruption in a developing nation. West. Polit. Q., 719-732.

Barbacetto, G., Gomez, P., \& Travaglio, M. (2012). Mani pulite. La vera storia, 20 anni dopo. Milano: Chiarelettere.

Barbieri, G., \& Giavazzi, F. (2014). Corruzione a norma di legge. Milano: Rizzoli.

Berrios, R. (2006). Government contracts and contractor behaviour. J. Bus. Ethics, 63(2), 119-130.

Bevir, M. (2006). Democratic governance: Systems and radical perspectives. Public Adm. Rev., 66(3), 426 -436.

Bourdieu, P. (1977). Outline of a theory of practice. Cambridge University Press.

Bovens, M. (2005). Public accountability. In E. Ferlie, L. Lynne, \& C. Pollitt (Eds.), The Oxford handbook of public management. Oxford: Oxford University Press.

Bovens, M. (2010). Two concepts of accountability: Accountability as a virtue and as a mechanism. West Eur. Polit., 33(5), 946-967.

Cassirer, E. (1991). Rousseau, Kant, Goethe (Vol. 440) Meiner Verlag.

Colazingari, S., \& Rose-Ackerman, S. (1998). Corruption in a paternalistic democracy: Lessons from Italy for Latin America. Polit. Sci. Q., 113(3), 447-470.

Cooper, D. J., \& Morgan, W. (2008). Case study research in accounting. Account. Horizons, 22(2), 159-178.

Corriere della sera. (2016). Verdini e Fusi, quindici anni di affari. [online]. Available at: http://www.corriere.it/cronache/10_maggio_05/verdini-fusi-affarigerevini_0f1bbc9c-584d-11df-b44b-00144f02aabe.shtml (accessed 16.02.16)

Corriere Fiorentino. (2010). Fusi, cinico e senza scrupoli come Piscicelli. [online]. Available at: http://corrierefiorentino.corriere.it/firenze/notizie/cronaca/ 2010/10-marzo-2010/fusi-cinico-senza-scrupoli-come-piscicelli-1602633927388.shtml (accessed 12.02.16)

Crouch, C., Eder, K., \& Tambini, D. (Eds.). (2000). Citizenship, markets, and the state. Oxford University Press.

De Graaf, G. (2007). Causes of corruption: Towards a contextual theory of corruption. Public Adm. Q., 39-86.

Della Porta, D., \& Vannucci, A. (1999). Corrupt exchanges: Actors, resources, and mechanisms of political corruption. New York: Walter de Gruyter, Inc.

Della Porta, D., \& Vannucci, A. (2005). Corruption as a normative system. In Prepared for presentation at the International Conference on Corruption control, in Political Life and the Quality of Democracy “A Comparative Perspective Europe-Latin America” (pp. 19-20).

Della Porta, D., \& Vannucci, A. (2007). Mani impunite. Vecchia e nuova corruzione in Italia.

Dobel, J. P. (1978). The corruption of a state. Am. Polit. Sci. Rev., 958-973.

Everett, J., Neu, D., \& Rahaman, A. S. (2006). The global fight against corruption: A foucaultian, virtues-ethics framing. J. Bus. Ethics, 65(1), 1-12.

Everett, J., Neu, D., \& Rahaman, A. S. (2007). Accounting and the global fight against corruption. Account. Organ. Soc., 32(6), 513-542.

Everett, J., \& Tremblay, M. S. (2014). Ethics and internal audit: Moral will and moral skill in a heteronomous field. Crit. Perspect. Account., 25(3), 181-196.

Flyvbjerg, B. (2004). Phronetic planning research: Theoretical and methodological reflections. Plan. Theory Pract., 5(3), $283-306$.

Flyvbjerg, B. (2006a). Making organization research matter: Power, values and phronesis. In The Sage handbook of organization studies. pp. 370.

Flyvbjerg, B. (2006b). Five misunderstandings about case-study research. Qual. Inq., 12(2), 219-245.

Fjeldstad, O. H., \& Tungodden, B. (2003). Fiscal corruption: A vice or a virtue? World Dev., 31(8), 1459-1467.

Foster, C. D., \& Plowden, F. J. (1996). The state under stress: Can the hollow state be good government? Buckingham: Open University Press.

Frederickson, H. G. (1996). Comparing the reinventing government movement with the new public administration. Public Adm. Rev., 56(2), 266-269.

Frederickson, H. G. (1999). Ethics and the new managerialism. Public Adm. Manag., 4(2), 299-324.

Gilmour, R. S., \& Jensen, L. S. (1998). Reinventing government accountability: Public functions, privatization, and the meaning of “State Action”. Public Adm. Rev., 247-258.

Graycar, A., \& Villa, D. (2011). The loss of governance capacity through corruption. Governance, 24(3), 419-438

Grossi, G., \& Reichard, C. (2008). Municipal corporatization in Germany and Italy. Public Manag. Rev., 10(5), 597-617.

Hansson, L., \& Holmgren, J. (2011). Bypassing public procurement regulation: A study of rationality in local decision-making. Regul. Gov., 5(3), 368-385.

Haque, M. S. (2001). The diminishing publicness of public service under the current mode of governance. Public Adm. Rev., 61(1), 65-82.

Hawkins, T. G., Gravier, M. J., \& Powley, E. H. (2011). Public versus private sector procurement ethics and strategy: What each sector can learn from the other. J. Bus. Ethics, 103(4), 567-586.

Hopkin, J., \& Rodríguez-Pose, A. (2007). “Grabbing Hand” or “Helping Hand”? Corruption and the economic role of the state. Governance, 20(2), 187-208.

Hoskin, K. (2015). "What about the box?" Some thoughts on the possibility of 'corruption prevention', and of 'the disciplined and ethical subject. Crit. Perspect. Account., 28, 71-81.

Il Fatto Quotidiano. (2016). Appalti G8, Cassazione conferma condanne a Balducci, De Santis, Fusi e Piscicelli per la scuola Marescialli. [online]. Available at: http://www.ilfattoquotidiano.it/2016/02/10/appalti-g8-cassazione-conferma-condanne-a-balducci-de-santis-fusi-e-piscicelli-per-la-scuolamarescialli/2452849/ (accessed 12.02.16)

Imarisio, M. (2010). Fusi e il memoriale alla procura "Sistema Balducci per appalti ai romani». Corriere della Sera [online]. Available at: http://www.corriere.it/cronache/10_giugno_13/imarisio-fusi-e-il-memoriale_12538e42-76c2-11df-9f61-00144f02aabe.shtml (accessed 12.02.16)

Johnston, M. (2015). Making transparency real? Accounting and popular participation in corruption control. Crit. Perspect. Account., $28,97-101$.

Kant, I. (1785). Groundwork for the metaphysics of morals.

Kateb, G. (1961). Aspects of Rousseau's political thought. Polit. Sci. Q., 76(4), 519-543.

Kelleher, C., \& Yackee, S. W. (2009). A political consequence of contracting: Organized interests and state agency decision making. J. Public Adm. Res. Theory, 19(3), 579-602

Kenny, C., \& Musatova, M. (2010). 'Red flags of corruption' in World Bank projects: An analysis of infrastructure contracts. In World Bank Policy Research Working Paper Series.

Khanal, R. (2000). Strategies in combatting corruption. In R. Khanal (Ed.), Transparency and accountability against corruption in Nepal (pp. 1-18). Kathmandu: Modern Printing Press.

Klijn, E. H. (2012). New public management and governance: A comparison. In D. Levi-Faur (Ed.), Oxford handbook of governance. Oxford: Oxford University Press.

Klitgaard, R. (1984). Managing the fight against corruption: A case study. Public Adm. Dev., 4(1), 77-98.

Klitgaard, R. (2014). Addressing corruption together. In Background paper prepared for the OECD Symposium on Anti-Corruption Development Assistance: Good Practices among Providers of Development Co-operation, which took place in Paris on December.

Kolthoff, E., Huberts, L., \& Van den Heuvel, H. (2006). The ethics of new public management: Is integrity at stake? Public Adm. Q., 399-439.

Kooiman, J. (Ed.). (2003). Governing as governance. Sage.

Kotera, G., Okada, K., \& Samreth, S. (2012). Government size, democracy, and corruption: An empirical investigation. Econ. Model., $29(6), 2340-2348$.

La Repubblica. (2013). Vent'anni di affari tra alleanze e processi. [online]. Available at: http://ricerca.repubblica.it/repubblica/archivio/repubblica/2013/09/06/ ventanni-di-affari-tra-alleanze-processi.html (accessed 16.02.16)

La Stampa. (2010). Così la cricca gestiva gli appalti. [online]. Available at: http://www.lastampa.it/2010/05/09/italia/politica/cos-la-cricca-gestiva-gli-appalti7W2KVxRpNz7y5YhgNPz3uM/pagina.html (accessed 12.02.16)

Lane, J. E. (1994). Will public management drive out public administration? Asian J. Public Adm., 16(2), 139-151.

L'Espresso. (2008). La lotta alla corruzione? Un bluff. [online]. Available at: http://racconta.espresso.repubblica.it/espresso-wikileaks-database-italia/ dettaglio.php?id=61 (accessed 13.02.16)

Lessig, L. (2011). Republic, lost. New York: Twelve.

MacIntyre, A. (2007). After virtue: A study in moral theory (2nd ed.). Notre Dame/Ind.

Marx, K. (1845). Theses on Feuerbach.

Ministry of Interior. (2012). Bill for the "Prevention and repression of corruption and illegality in the Public Administration". Rome. 
Morales, J., Gendron, Y., \& Guénin-Paracini, H. (2014). State privatization and the unrelenting expansion of neoliberalism: The case of the Greek financial crisis. Crit. Perspect. Account., 25(6), 423-445.

Mulgan, R. G. (1979). Lycophron and Greek theories of social contract. J. Hist. Ideas, 121-128.

Murray, J. G. (2009). Improving the validity of public procurement research. Int. J. Public Sector Manag., 22(2), 91-103.

Neu, D., Everett, J., Rahaman, A. S., \& Martinez, D. (2013). Accounting and networks of corruption. Account. Organ. Soc., 38(6), 505-524

Neu, D., Everett, J., \& Rahaman, A. S. (2015). Preventing corruption within government procurement: Constructing the disciplined and ethical subject. Crit. Perspect. Account., 28, 49-61.

Noone, J. B. (1970). The social contract and the idea of sovereignty in Rousseau. J. Polit., 32(3), 696-708.

Nussbaum, M. C. (1990). The discernment of perception: An Aristotelian conception of private and public rationality. In Love's knowledge: Essays on philosophy and literature. pp. 54-105. Oxford: Oxford University Press.

Osborne, S. P. (Ed.). (2010). The new public governance: Emerging perspectives on the theory and practice of public governance. Routledge.

Osborne, D., \& Gaebler, T. (1993). Reinventing government: How the entrepreneurial spirit is transforming the public sector. New York: Penguin Books.

Papadopoulos, Y. (2007). Problems of democratic accountability in network and multilevel governance. Eur. Law J., 13(4), 469-486.

Plato, The Republic.

Popper, K. R. (1966). The open society and its enemies. Princeton, NJ: Princeton University Press,

Roberts, J. (2015). The 'subject' of corruption. Crit. Perspect. Account., 28, 82-88.

Rose-Ackerman, S. (2000). Is leaner government necessarily cleaner government? Combat. Corrupt. Lat. Am., 87-104.

Rose-Ackerman, S., \& Stone, A. (1996). The costs of corruption for private business: Evidence from World Bank surveys. Washington, DC: The World Bank.

Rousseau, J. J. (1762). The social contract.

Sargiacomo, M., Ianni, L., D’Andreamatteo, A., \& Servalli, S. (2015). Accounting and the fight against corruption in Italian government procurement: A longitudinal critical analysis (1992-2014). Crit. Perspect. Account., 28, 89-96.

Schwartz, B. (2011). Practical wisdom and organizations. Res. Organ. Behav., 31, 3-23.

Sen, A. (1999). Development as freedom. Oxford University Press.

Shearer, T. (2002). Ethics and accountability: From the for-itself to the for-the-other. Account. Organ. Soc., 27(6), 541-573.

Shleifer, A., \& Vishny, R. W. (2002). The grabbing hand: Government pathologies and their cures. Harvard University Press.

Sikka, P., \& Lehman, G. (2015). The supply-side of corruption and limits to preventing corruption within government procurement and constructing ethical subjects. Crit. Perspect. Account., 28, 62-70.

Soudry, O. (2007). A principal-agent analysis of accountability in public procurement. In Advancing public procurement: Practices, innovation and knowledgesharing. pp. 432-451.

Stiglitz, J. E. (1989). The economic role of the state.

Thompson, D. F. (1980). Moral responsibility of public officials: The problem of many hands. APSR, 74, 905-916.

Valkama, P., Bailey, S. J., \& Anttiroiko, A. V.(2013). Analyzing organizational innovation in public services-Conceptual and theoretical issues. In Organizational innovation in public services: Forms and governance. pp. 27.

Vannucci, A. (2009). The controversial legacy of 'Mani Pulite': A critical analysis of Italian corruption and anti-corruption policies. Bull. Ital. Polit., 1(2), 233-264.

Wolgast, E. (1994). A world of social atoms. In S. Elizabeth, \& H. G. Blocker (Eds.), Applied social and political philosophy (p. 226). Englewood Cliffs, NJ: Prentice-Hall.

Yin, R. (2003). Case study research: Design and methods. London: Sage Publications.

\section{Primary sources}

\section{National laws and decrees}

Law n. 367/2001. Ratification and implementation of the Agreement between Italy and Switzerland.

Law n. 248/2002. Amendment of Articles 45, 47, 48 and 49 of the Code of Criminal Procedure.

Law n. 140/2003. Provisions implementing Article 68 of the Constitution as well as in the area of criminal proceedings against the high offices of state.

Law n. 241/2006. Collective Clemency Bill.

Law n. 124/2008. Regulations on the suspension of criminal trials to high-ranking State offices.

Law 401/2001. Conversion of the Decree Law n. 343/2001 on urgent measures to ensure the operational coordination of structures for the civil protection activities.

Legislative Decree n. 163/2006. Code of public contracts for works, services and supplies in implementation of Directives 2004/17/EC and 2004/18/EC.

Law n. 136/2010. Extraordinary plan against mafias and mandate to the Government in the matter of anti-mafia rules.

Law 190/2012. Provisions for the prevention and suppression of corruption and unlawfulness in Public Administration.

Law 69/2015. Law on corruption in the Public Administration, organized crime and against false accounting.

Law 286/2006. Conversion of the Decree Law n. 262/2006 on urgent measures in taxation and finance.

Decree of the President of the Council of Ministers, 23 November 2007. Declaration of the celebration of the 150th anniversary of Italian unification as a big event.

Decree of the President of the Council of Ministers, 21 September 2007. Declaration of the G8 Summit of 2009 as a big event.

Pre-trial detention order-Tribunale ordinario di Firenze. Ordinanza di applicazione della misura cautelare della custodia in carcere. Proc. n. 14867/08 R.G. notizie di reato. Proc. n. 1460/09 R. G.I.P.

Verdict document-Tribunale ordinario di Roma. Sentenza nei confronti di Balducci Angelo, De Sanctis Fabio, De Vito Piscicelli Frencesco Maria.

\section{Miscellaneous}

ANAC. (2013). Corruzione sommersa e corruzione emersa in Italia: modalità di misurazione e prime evidenze empiriche.

ANAC. (2014). Piano di riordino. Available at. http://www.anticorruzione.it/portal/public/classic/AttivitaAutorita/PianoRiordino (accessed 12.02.16)

Eurobarometer. (2015). Businesses' attitudes towards corruption in the EU.

European Commission. (2014). EU Anti-Corruption Report.

European Commission. (2014a). EU Anti-Corruption Report Italy.

European Commission. (2014b). EU Anti-Corruption Report Greece.

European Commission. (2014c). EU Anti-Corruption Report Denmark.

European Commission. (2014d). EU Anti-Corruption Report Sweden.

European Commission. (2014e). EU Anti-Corruption Report Finland.

GRECO-Group of European States against corruption. (2008). Evaluation Report on Italy. Strasbourg: Council of Europe. Greco Eval I/II Rep (2008), July 2, 2009.

International Monetary Fund. (2005). Back to basics-10 myths about governance and corruption.

OECD. (2001). Cities for Citizens: Improving Metropolitan Governance. Paris: Organisation for Economic Co-operation and Development.

OECD. (2013a). Integrity Review of Italy. Reinforcing public sector integrity, restoring trust for sustainable growth. OECD Public Governance Reviews, OECD Publishing. 
OECD. (2013b). The rationale for fighting corruption. Available at. http://www.oecd.org/cleangovbiz/49693613.pdf (accessed 12.02.16) OECD. (2015). Economic Surveys ITALY. Available at. http://www.oecd.org/eco/surveys/economic-survey-italy.htm (accessed 12.02.16) Transparency International. (2011a). Countries performing well in the CPI.

Transparency International. (2011b). National Integrity System Assessment. Italy. Available at. http://www.transparency.org/whatwedo/nisarticle/italy_2011 (accessed 12.02.16)

Transparency International. (2013). Global Corruption Barometer. Available at. http://www.transparency.org/gcb2013 (accessed 18.05.16) Transparency International. (2014). Brazil: Overview of corruption and anti-corruption.

Transparency International. (2015). Corruption Perceptions Index. Available at. http://www.transparency.org/cpi2015 (accessed 18.05.16)

United Nations Office of Drugs and Crime. (2013). Guidebook on Anti-Corruption in Public Procurement and the Management of Public Finances: Good Practices in Ensuring Compliance with Article 9 of the United Nations Convention Against Corruption.

World Bank. (1997). Helping countries combat corruption: The role of the World Bank. Washington, DC: World Bank.

World Bank. (2013). Control of Corruption Index (CCI). Available at. http://info.worldbank.org/governance/wgi/index.aspx\#reports (accessed 12.02.16) 